ing must be considered as a distinctly long-term project and therefore must be approached with a long-term viewpoint. Working in the woods is a change from working in the open fields or farm yard, for it offers the nearest thing we have to primeval conditions and completes the picture of a well balanced farm which gives those human satisfactions that we call a way of life to men and women who enjoy country living.

\section{Nature's Simple Pleasures}

\section{By Mrs. Hilda Newton \\ Lake Marguerite, Indian Head}

In early summer we found, when wiring the home for electricity, a family of bats who were quite comfortable "hanging" around the brick chimney in the attic, keeping warm during the damp chilly days of May and June. As soon as the sun popped from sight, out they would come, squeaking like tiny mice, busily searching around eaves and windows for flies and moths. We found very few of those large Blue Bottles - Nature's strange creatures are here for a purpose, so the family were not disturbed.

The cold wet summer must have been hard on the young birds. We did not see many Meadowlarks or Bluebirds this year - only one flock of about twenty Bluebirds during the last week of September. Song Sparrows and Grasshopper Sparrows were very plentiful. We did miss the rollicking song of our Western Meadowlark, who by the way, can out-do his Eastern cousins in gayety. I was sure Ontario didn't have any until, one day, hearing the strange song, I hurried out to see - a meadowlark! He w a s familiar in size and dress, but the song, though not unmusical, wasn't nearly so merry.

How many, like myself, thought our Prairie Lily was a native of our western provinces only? When going east by train in early July, I was delighted to see so many along the line, until just past Bran- don. Then again, after Fort William, on along the shore of Lake Superior were red patches, some bravely nodding to us from the bare rocks. One wonders where they could find sufficient food.

There were also dwarf bushes of deep red roses, covered with blooms. Further on these were replaced by dainty clusters of Blue Iris, reflected in the tiny pools. Moutain Ash were white with bloom and peeping from under the evergreens were hundreds of tiny flowers, perhaps Hapaticas. Very late, we thought, but snow stays late in the deep woods.

\section{Bird Migration Study}

Mrs. C. E. Boon, Tullis, Sask.

I note you were disappointed that the Migration Study covered only the eastern half of the province. The simple reason for that may be that we, in the western half, just don't see many of these birds.

This is the typical bald prairie. The only trees anywhere close are man-planted. I have no doubt that many, or all, of the birds pass through, but they waste no time about it. If one happens to be out when they are going through, you see them - if not, you don't. I suppose the solution is to spend more time in the field, but that's not always easy.

I started to keep a record and ended up with only eight, out of twentynine. Only once have I seen a spring migration of warblers. That was in May, 1950. It was cold and windy and they were in hundreds among the bushes in the coulee. That was in the evening. Next morning they were gone. They were Yellow and Myrtle Warblers. There are ten birds on that list I have never seen here at all.

I have had reports of two Whooping Cranes among the Sandhill Cranes on the river. I haven't seen them myself, and with everyone seeing Whooping Cranes in anything white (which is a good thing) one is apt to be rather sceptical. We saw one several times with the Sandhill Cranes in 1949. Once seen, there is no mistaking them. 